\title{
DIHOTOMIJA SLIKE SVIJETA U DRAMSKOM STVARALAŠTVU ALIJE ISAKOVIĆA
}

\section{Sažetak}

U svim se Isakovićevim ostvarenjima mogu nočiti slike prošlog $i$ slike savremenog, historijska i ovovremena slika svijeta. Ipak, i u jednom i u drugom slučaju, u cjelini, Isaković traga za nepromjenljivom slikom ljudske dvojnosti, on je sav u naporu označavanja krajnosti ljudske egzistencije, neprekidnom srazu gradilačkog $i$ rusilačkeog principa, koje ćmo jednako prepoznati $i$ u kozmičkom i u antropološkom, i u prošlom i u sadašnjem. On daje analitičke slike odraza i obrisa u ljudskim postupcima i stvarima i pojavama oko njih, te se ti obrisi mozaički slažu u više ili manje cjelovit $i$ koherentan pripovijedani motiv, upravo skup, snop analitickeih podataka obicno bez. zaključenih sinteza, sa objektivistički otvorenim slikama za critalačko opredjeljenje $i$ zakljućak. Kao dramski pisac (To, Generalijum, Hasanaginica...), Isaković ce se realizirati krajem sedamdesetih $i$ početkom osamdesetih godina prošlog vijeka. On spada u grupu dramskih pisaca koji u tom periodu istražuju moderni teatar i preispituju utjecaje modernog teatra. Zagledan je u prošlost, korespondirajuci sa suvremenošcu, on se vezuje za našu domaín bošnjačku knjǐ̌evnu, narodnu i kulturnu tradiciju, koju, dakle, oblikuje na nov originalan način, izvlačeći univerzalne poruke $i$ smisao.

Ključne riječi: Alija Isaković, dihotomija svijeta, dva prezenta, dramsko stvaralaštvo, poetika, To, Generalijum, bošnjačka narodna balada Hasanaginica, dijalozi, monolozi, didaskalije, egzistencijalizam, apsurd, mit, historija, antagonizam...

\section{1) Uvod (Književna poetika Alije Isakovića ili odraz historijske i ovovremene slike svijeta)}

U svim se Isakovićevim ostvarenjima mogu uočiti slike prošlog i slike savremenog, historijska i ovovremena slika svijeta. Ipak, i u jednom i u drugom slučaju, u cjelini, Isaković traga za nepromjenljivom slikom ljudske dvojnosti, on je sav u naporu označavanja krajnosti ljudske egzistencije, neprekidnom srazu gradilačkog i rušilačkog principa, koje ćemo jednako prepoznati i u kozmičkom i u antropološkom, i u prošlom

${ }^{1}$ Islamski pedagoški fakultet u Bihaću. 
i u sadašnjem. Isakovićeve proze, pa i onda kada nisu kazivane u prvom licu, imaju naglašenu subjektivnu boju doživljenosti i stvarnosti težine, i najvećim dijelom su angažirano vezane za našu suvremenost, za psihologiju našeg suvremenika.

Ponajbolje je to prepoznao Ivan Lovrenović u jednoj fusnoti svog teksta Svijet u prezentu: „Karakteristicna je u Alije Isakovica ta intermedijska adaptabilnost tekstova: veoma lako $i$ veoma prirodno njegove se pripovijetke pretvaraju u tv i radiodrame, $i$ obratno, tako da je katkad teško ustanoviti sta je čmu prethodilo. U ovoga autora ta osobina očito je nešto više od pukoga kronološkobibliografskoga redoslijeda; ona predstavlja jednu od unutrašnjih zakonitosti njegova stvaranja, čemu bi bilo zanimljivo posvetiti posebnu stručnu-teorijsku paそ̌nju. "

Mahom je uvijek u pitanju suočenje sa nekim zaprekama da se oživotvori međuljudski odnos dostojanstva i intimnog saobraženja sa svijetom, moralno-psihološkim stanjima i zapletima. Isaković daje analitičke slike odraza i obrisa u ljudskim postupcima i stvarima i pojavama oko njih, te se ti obrisi mozaički slažu u više ili manje cjelovit i koherentan pripovijedani motiv, upravo skup, snop analitičkih podataka obično bez zaključenih sinteza, sa objektivistički otvorenim slikama za čitalačko opredjeljenje i zaključak. Znači, očita je piščeva korespondencija u tematskom smislu sa suvremenošću. Uz to, gramatička dominanta Isakovićevog teksta je prezent. Ustvari, izrazita međuzavisnost "dvaju" prezenta ("prezenta" promatranoga svijeta i života, i prezenta u jeziku), jedan je od konstitutivnih elemenata Isakovićeve poetike. Također, u cjelini, Isaković je njegovao dva tipa proze: introspektivno-monološki i dijaloški (npr. Generalijum i Takođe). I u svom dramskom opusu, Isaković je zagledan u prošlost, korespondirajući sa suvremenošću, on se vezuje za našu domaću bošnjačku književnu, narodnu i kulturnu tradiciju, koju, dakle, oblikuje na nov originalan način, izvlačeći univerzalne poruke i smisao. (npr. Hasanaginica). Njegove drame imaju izuzetan dramski naboj. One imaju i izuzetan dijalog: čist, jasan, sočan, pun dramskog intenziteta i psihološke težine... Isaković donosi punu i dinamičnu "dramsku radnju", rastače sadržajnu i psihološku fakturu, podcrtava uvijek izuzetnu, neobičnu i neodgonetljivu situaciju iz koje, analitički precizno i poetski sugestivno, miče i širi bogatu, slojevitu i privlačnu dramsko-psihološku materiju. Radi se, dakle, ujedno, o promišljenoj kombinaciji arhaične jezičke patine i zgusnute

2 Lovrenović, Ivan, Svijet u prezentu, predgovor knjizi A. Isaković, Taj covjek - Pobuna materije, Sarajevo 1991., str. 7. 
metaforike narodnog govora. O Isakovićevom književnom djelu pisali su brojni istaknuti književnici i književni kritičari: M. Begić, E. Duraković, T. Kulenović, G. Muzaferija, I. Lovrenović, M. Rizvić i drugi.

Sve Isakovićeve drame, osim drame Hasanaginica, se kreću u vremenskom razdoblju između dva svjetska rata, ali sve tematiziraju različitu problematiku. Kao dramski pisac, Isaković će se realizirati krajem sedamdesetih i početkom osamdesetih godina prošlog vijeka i on spada u grupu dramskih pisaca koji baš u tom periodu istražuju moderni teatar i preispituju utjecaje modernog teatra. Tako se Isakovićeve drame odlikuju dokidanjem do tada forsirane realističke tradicije, te se on, kao i većina dramskih pisaca toga doba, bavi sa raznim scenskim ispitivanjima, tako da su njegove drame prepune naturalističkih, neosimbolističkih i egzistencijalističkih elemenata, što je naročito izraženo u slijedeće tri drame:

\section{2) Dramski tekst To, prva bosanskohercegovačka tv-drama kao eksperimentiranje sa egzistencijalističkom poetikom}

U drami To (1981.) radnja se zbiva između dva svjetska rata u krčmi Kod slavuja (ali se vrijeme radnje može posmatrati i kao univerzalno, opće vrijeme), tamo gdje zaokreće električni tramvaj (neki prostor iznutra, omeđen sa četiri zida i odijeljen od vanjskog svijeta). Dosljedno je ispoštovano klasično jedinstvo vremena, mjesta i radnje.

To je i prva bosanskohercegovačka drama koja je pisana za televiziju i koja je u svoje vrijeme izazvala pravu senzaciju, a izaziva je i danas. Ono što je Isakovića prvenstveno izdiferenciralo kao dramskog pisca je to da se on kao dramski autor prvenstveno izgrađuje kroz radiodrame, pa su njegovi dramski tekstovi obilježeni tom specifičnom vrstom, što je rezultiralo tim da su njegove drame izgrađene od pomno razrađenih dijaloga koji tkaju dramski naboj.

Možda je Isakovićevo izgrađivanje u vrsnog dramskog pisca preko radiodrame, TV-drame, pa do pozorišne scene i djelovalo na to da on spada u onu skupinu dramatičara koji insistiraju na tezi da dramski dijalog mora biti što bliži prirodnom, razgovornom jeziku. Zbog toga je za razumijevanje njegovih dramskih dijaloga potrebno ono što se često obilježava kao "okvir" ili "scenarij" situacije. Dakle, potrebno je predznanje o određenim cjelovitim životnim situacijama i općenito o svijetu u cjelini koji podrazumijeva određene i ukalupljene kognitivne 
sheme. Kod recipijenata moraju postojati usađene zajedničke pretpostavke o situacijama u kojima se javlja izrečeni dijalog kojeg oni percipiraju i spajaju sa svojim predznanjem o situaciji koja se prikazuje.

Marina Katnić-Bakaršić u svom jedinstvenom radu na ovim područjima Stilistika dramskog diskursa, izdvaja Isakovićeve dramske dijaloge koji na najljepši način prikazuju kako se kognitivno sažimaju recipijentsko predznanje o datim situacijama i dramski dijalog koji se nudi na recepciju. Ovdje su didaskalije sa uvodom i opisom prosto nepotrebne, jer se iz kratkog dijaloga jasno percipira da se radi o kafani i o konobaru koji uslužuje novopridošlog gosta. Čak je i sam dijalog reduciran na samo one osnovne riječi koje su inače uobičajene za ovakav tip komunikacije, ali to ne uskraćuje značenje, nego se naprosto dovodi do toga da je gotovo potpuno izjednačen dramski dijalog sa prirodnim, razgovornim dijalogom, što svakako u ovom slučaju predstavlja i svojevrsnu markiranost u tekstu, jer je radnja smještena upravo u kafanu, baš ondje gdje je ovakav razgovor poput bujice. Osim toga, ovakav nastup konobara nam jasno govori o kakvoj se vrsti kafane radi, da to nije neka otmjena i profinjena, skupa, elitna kafana, već ona obična, radnička, gdje se puno pažnje ne posvećuje manirima.

To je dovelo i do toga da je u većini njegovih drama scenski prostor uglavnom nedefiniran, neodređen, ali je zbog toga pomno razrađen uticaj različitih zvukova na tkanje dramskog naboja, te psihološka težina dramskog zapleta. Kako je to primijetio Slavko Šantić, Isakovićeva drama To se može posmatrati i kao svojevrstan eksperiment jer prolazi zanimljiv put od radiodrame, preko televizijskog medija, pa do kazališne scene. Junaci ove drame su individualno nedefinirani, oni su bez imena i prezimena, to su tek nadimci ili naznačene profesije, srodstva ili životne dobi, tako da percipiranjem ove drame, bez obzira ko bili, možemo da se poistovjetimo sa nekim od ovih likova, ali ne samo sebe, već i sve koje poznajemo, a to je način na koji nas Isaković uvodi u univerzalnost egzistencijalnih problema malih i običnih ljudi. Na početku drame, osobena je idilična, mirna atmosfera bosanske kafane, uljuljkana u tihi, svakodnevni monotoni razgovor. Jedino što je remeti je povremeni, ali nagli, prolazak tramvaja pod čijim dejstvom nastaje blagi zemljotres koji proizvodi zvukove drhtaja stakla i nagovještava nam da je idila samo vizualno statična $i$ da se svaki čas ona može poremetiti. Ovakva koncentracija radnje na jednom zatvorenom i bezizlaznom mjestu, dovela je do toga da kafana postaje simbolom života, u njoj se isprepliću ljudi i njihove raznolike sudbine. Nakon ulaska Brata u kafanu, ta mirna 
atmosfera naglo se remeti i dolazi do dramatičnog zapleta već u samom uvodnom dijelu drame. Time je Isaković napravio oneobičavanje dramske strukture, jer nije išao klasičnim redoslijedom polaganog zaplitanja radnje, već naglim ulaskom Brata započinje retrospekcija i kulminacija. Brat koristeći silu tiranizira sve ljude u kafani i upravo tu progovaraju naturalistički elementi, ali su oni iskorišteni samo za duboku psihološku karakterizaciju likova, koja je upravo dovela do toga da se nasilje percipira kao bit postojanja.

U prvi mah čini se da je ovo drama o krvnoj osveti, ali uskoro na vidjelo izbija njen univerzalistički karakter, gdje kafana predstavlja simboliku tamnice $\mathrm{i}$ zatočeništva ljudskog roda u njegovom životu. Saznajemo da Brat sa izigravanjem terora i traženjem krvne osvete jednostavno želi ubiti krivca u sebi i pobjeći od istine da je ustvari on ubio vlastitog brata $i$ to u trivijalnoj i morbidnoj svađi oko međe. Klasična dramska akcija je zamijenjena psihološkim sukobima, sudarima ljudskih strasti. Do kulminacije dramskog sukoba dolazi upravo kroz malu psihoigru koju je Doktor vješto smislio da bi pokušao urazumiti Brata, kada su svi ostali verbalni pokušaji već propali. Dolazi do svojevrsne inverzije dramske situacije, jer sada strah sa svih prelazi upravo na onoga koji je širio strah i teror, a to je sam Brat kao simbol samoproglašenog silnika, bratoubice, koji uporno prikriva svoj zločin i prebacuje ga na druge.

Ovdje je najizraženija tehnika obrata kojom Isaković oslikava likove u ovoj drami i tako dovodi do postepenog otkrivanja dvosmislenosti ukupnog ljudskog ponašanja, gdje svako od nas nosi neku masku preko pravog lica, i stoji u vječitom sukobu između onog što nas progoni i između onog što mi progonimo.

„Brat: Tvoje oko doktursko ne mere mene dokuciti!

Doktor: Sam strahiješ, a nas plašišs! Probada te nešto, muklo!

Brat: Ne spominji mi probadanje!

Doktor: A, tako! Ne spominji! Jede te nešto!" "3

Nakon Doktorove mudre psihološke igre sa pijanim i nervno rastresenim Bratom, dolazi do kulminacije, Brat biva primoran da se

${ }^{3}$ Isaković, Alija, To, Drame, "Preporod", Sarajevo, 1995., str. 111.-112. 
suoči sam sa sobom, da skine onu lažnu osvetničku masku sa lica i da se suoči sa činjenicom da on ustvari progoni samoga sebe.

„Brat, među njima kao zvijer... Lutvo je svemu kriv... $i$ za zemlju $i$ za Omera... Halil je řvivi svjedok! (Presječe ga novo lupanje na vratima $i$ neki glasovi nerazgonovijetni. Brat se malo pridiže, očju qakrvavljenib) Kad smo se podijelili poslije Salkine smrti - rekli smo cije je rijje! ...Ne dam svoje hise! Ne dam!... Niko ne zna kakav je Lutvo bio krmak! (Lupanje i glasovi. Brat podiže noそ̌, uspravi se) $\mathrm{Ne}$ dam! Što je moje, moje je! Lutvo je sevep, zna Halil! (Koraknu vratima) Udite da ínjem kako prskaju dř̃avna vrata! ...Ne dam ja sebe ni Bogu ni ljudima! Ne dam! Ne! Poluokrenut na sceni, prignut vratima, zari sebi nož svom snagom $i$ pade) "4

Brat radije bira smrt, nego da živi sa spoznajom svoga pravoga ja koje nije ništa drugo nego oličenje zla. On postaje svjestan da iz zla može samo da se rodi novo zlo i odlučuje da je smrt njegov jedini izlaz iz tog apsurdnog osjećaja u kojem se nalazi. Po tom se ova drama najviše približava drami apsurda, ona emanira zatvoreni kafanski krug u kojem je sva tenzija izgrađena na psihološkom varničenju između likova, recipijenti stalno očekuju da se nešto dogodi, bilo to izvršenje Gostovog pogubljenja zbog lažne krivice, ili neka intervencija iz vanjskog svijeta. Elemente uzaludne pobune protiv apsurda unosi lik Nosača, koji je okarakteriziran kao "zdrav" čovjek i kao jedini koji se pokušava suprotstaviti tiraniji Brata, ali i on, nakon grubog udarca, pruža sliku potpune predaje dok pije ležeći na podu. On odustaje od svake vrste djelovanja, pa makar i onog apsurdnog. Uvođenjem sporednih sekvenci, prvenstveno Starca i Starice, održava se taj dojam apsurda, jer oni sa svojim ispraznim dijalozima, koji su inače nevezani za dramsku radnju, ukazuju koliki je besmisao u pokušaju ljudi da pronađu način komunikacije koja će biti svima razumljiva, oni odaju samoću i tihu smrt u samoći.

„Starica: Možda bi malo jetre na žaru? (Hǚe u promržle prste) Dok smo se klatarili hladnim tramvajem, spominjao si jetru na žaru. Cak si Tramvajd乏̌iji spominjao jetru na žaru. Jedva te razumio, dragi.

Starac: Morao sam nešto da kažem. Koliko je trajalo dok smo krenuli sa Malte!

4 ibid, str. 116. 
Starica: Sad smo tu, i dobro bi bilo zaboraviti taj tramvaj... (Tramvaj zapara sinama...)

Starac: Ti si prva spominjala jetru na そ̌aru.

Starica: Ne, dragi, nikad ja nisam voljela jetru, sjećaš se? (Pogleda ga suučesnički, samilosno)

Starac: Ne, ne! Ti si tako voljela mladu jetru. Kad bi bila pauza u Direkciji, trčala si ovdje, Kod Slavija, zajapurena.

Starica: Ne, dragi. Ti si redovno dolazio u Poštu-1, s toplim somunom $i$ jetrom-res. " 5

Ovo je očigledni primjer apsurdnog razgovora koji nam odaje da je ljudima, ma koliko dugo živjeli skupa, nemoguće da pronađu zajedničku komunikaciju, i da je zbog toga čovjek, bez obzira na to koliko se trudi, osuđen na potpunu samoću. Drama počinje ovim apsurdnim dijalogom Starca i Starice, a ujedno tako i završava, zatvarajući u krug dramsku radnju u Kafani kod Slavuja. Sam kraj predstave je otvorenog tipa, jer nam ostavlja zaključak da zlo nije moguće ubiti, zlo je moguće samo zaboraviti, a to ne nudi nikakvo rješenje čovječanstvu, pa je s toga i čovječanstvo samo po sebi apsurdno. U završnoj didaskaliji Isaković naglašava ....i kad su došli na kraj, umjesto da sve bude prekriveno, sve je opet otvoreno...

\section{3) Generalijum ili dramska alegorija sukoba dobra i zla}

U drami Generalijum (1981.) radnja se odvija uoči Drugog svjetskog rata u vojnoj karauli-osmatračnici, na $2082 \mathrm{~m}$ nadmorske visine. Kao i kod drame To, dosljedno je ispoštovano klasično jedinstvo vremena, mjesta i radnje.

Ova drama je još više nego drama To, načinjena od psiholoških sukoba tako da gotovo i nema klasične dramske radnje. Ona je sva u naelektrisanim psihološkim sudarima između aktera ove drame (Narednika i Vojnika), koji ustvari predstavljaju personifikaciju sukoba dobra i zla, planirane torture i individualne slobode. Tako se Generalijum može shvatiti kao dramska alegorija sukoba dobra i zla, i prkosnog otpora tiraniji, kao etičko propitivanje ovog vječitog sudaranja poroka i vrlina.

${ }^{5}$ Isaković, Alija, To, Drame, "Preporod", Sarajevo, 1995., str. 28.-29. 
Sve je - kako bi Lovrenović kazao - u logici i optici. I jezik i sintaksa su prilagođeni takvoj vrsti teksta. Rečenice su ili jako kratke, često upravo programski svedene na samo jednu riječ, ili opet jako duge, raširene na nekoliko desetina redova, sve u nabrajanju. Radnja je na tipični Isakovićev način izolirana, zatvorena, skučena u neku pograničnu vojničku karaulu koja je potpuno izolirana od vanjskog svijeta i predstavlja bezizlazni pakao. Jedini znakovi vanjskog svijeta i nade u njegovo postojanje su razni glasovi koji se ponekad čuju, a koji su predstavljeni u nerazumljivoj kombinaciji Morzeovih znakova, radijskih hvalospjeva o kraljevskoj dinastiji i isprekidanih vijesti sa ratišta. Ovaj skup izmiksane akustike ujedno označava i samu besmislenost zatvorenog svijeta Karaule, te apsurdnost same dramske situacije. Hronološki je radnja smještena pred sam početak Drugog svjetskog rata na vrhu snijegom zatrpane planine Vitorog u zabačenoj i odsječenoj vojnoj karauli. U tom izolovanom svijetu Isaković kreira psihološku dramu u kojoj su glavni akteri zarobljeni, bez izlaza.

Mladi Vojnik predstavlja personifikaciju slobode vlastitog izbora, a ujedno i onog hrabrog pojedinca koji se usuđuje suprotstaviti tiraniji koju provodi Narednik. Sama Karaula postaje jedna velika alegorija tiranije i trpljenja, sile i otpora, a Vojnik simbol veličine vlastitog žrtvovanja radi življenja principa dobra. Likovi su istovremeno i personifikacije, ali i konkretni likovi sa izgrađenim karakterima, sa svojim malim biografijama i sa svojim malim životima.

Sukob, naizgled, započinje oko apsurdne stvari, kao što je slomljeni ključ, ali je osnova toga sukoba u ideološkom strahu pomalo sadističkog i opsesivnog Narednika/vlasti od onoga što mladi Vojnik simbolizira, a to je slobodno razmišljanje samosvjesnog individualca koji se usuđuje sve analizirati i kritizirati, pa tako i samu trulost državnog sistema. Upravo će taj sukob prerasti u osnovni tok dramske radnje, u stalno sučeljavanje dva konstruirana antipoda Narednika (tvrd, bahat, zadrt) i Vojnika (inteligentan, mehak, tih). Vojnik na početku sukoba biva i sam zbunjen sa brutalnošću narednika koji mu daje zadatak koji je naprosto neizvodljiv i koji ga samo može odvesti u ledenu smrt, ali tada odlučuje da će izvršiti zadatak, da će čak i žrtvovati svoj vlastiti život negdje u nedođijama Vitoroga, ali će bar prije toga verbalnim obračunima dokazati da se svaka sila može uzdrmati iz svog temelja. Vojnik uspijeva da svojim filozofskim replikama uzdrma temelje onoga na čemu je izgrađena narednikova sadističko-vojnička sila i postepeno odumire njegova prepotentna oholost, ali ujedno dolazi i do grozne samospoznaje 
koliko su vlastiti životni principi pogrešni i iskrivljeni, temelji na kojima su oni sazdani nemaju ama baš nikakvog smisla.

Slično kao u drami To, dolazi do psihološkog obrata lika koji je glavni nosilac negativnih osobina, pa tako Narednika, nakon vojnikovog odlaska obuzima talas grižnje savjesti koja ga postepeno vodi do potpunog ludila. Na samom kraju drame Narednik doživljava potpuni psihološki kolaps, i to baš u onoj simboličnoj sceni kada donose smrznuto vojnikovo tijelo, i kad svi zapažaju kako on u smrznutoj ruci, gotovo prkosno, drži traženi ključ, ali ključ niko ne može izvaditi. Kraj je tako razriješen u pobjedi dobra nad zlom, na jedan pomalo tragičan način, ali ipak zlo biva uzdrmano iz svojih temelja $i$ ona sila koja je progonila dobro se vraća kao bumerang i uništava ga.

„Narednik: Umro je, ali je iquršrio naređenje .

Narednik uze pušku sa bajunetom. Naglo se okrene prema vojnicima.

Narednik: To je vojnik, a ne vi!

Niko mu ne odgovara

Narednik: To je bio vojnik, a vi ste sitno civilno smé́e.

Priđe vojniku.

Narednik: To je bio vojnik, majko mila! To je bio vojnik! To je bio vojnik!

Plače bez suza. Snažnim udarcem zabode pušku s bajunetom u sto. Stade mirno.

Suze mu klize niz lice.

Vojnici: Naš generalijum je lud! Naš generalijum je lud!... “6

Prostorno-vremenska zatvorenost u ove dvije drame ima posebnu funkciju izolacije od vanjskog svijeta koji se nagovještava samo namjernim šumovima koji emaniraju osjećaj tjeskobe, bezizlaznosti i determinističku koncepciju likova. Likovi su zarobljeni u svojoj sredini i ona im ne dopušta nikakve promjene, nego ih deformiše u nekoj nezdravoj statičnosti i apsurdnoj ukočenosti. Vremenska zatvorenost ima funkciju da prezentira neizbježni tok događanja koja su nužno fatalistički razriješena od svih napetosti koje su rezultat prošlih događanja. Po tim

${ }^{6}$ Isaković, Alija, Generalijum, Drame, "Preporod", Sarajevo, 1995., str. 208. 
elementima, ove dvije Isakovićeve drame možemo svrstati u one sa naturalističkom notom koje su uvijek okrenute toj prostorno-vremenskoj zatvorenosti u želji da se identificira realno vrijeme predstave i fiktivno vrijeme dramske igre u cilju što većeg intenziteta neposrednosti prikazivanja.

Ovakva konstrukcija drame epiziranjem putem zatvaranja likova u prostorno-vremenski totalitet iz kojeg nema izlaza, nego kontrast vanjskog svijeta biva postignut nekim audio ili vizualnim zvukovima, izaziva otuđenje dramskog svijeta iz područja svakodnevnog i onog što je očekivano. $\mathrm{Na}$ takav način, putem otuđenja, oba ova dramska prikaza postaju kritička reprodukcija stvarnosti.

\section{4) Hasanaginica, dramski tekst između historije i mita}

Isakovićeva drama Hasanaginica obuhvata vrijeme prve polovine XVII stoljeća, vrijeme Kandijskog rata u kojem se nazire potresanje gigantskog Osmanskog carstva. Historijska podloga za dramski tekst o Hasanaginici su balada i legende. Balada o nesretnoj Hasanaginici nastala je u Imotskoj krajini, na mjestu odakle se u daljini naziru vrletni visovi divlje planine Biokovo. Osnovni tok baladne radnje dešava se u mjestu Vrdol, današnji Zagvozd i Župa, gdje je čuveni Hasan-aga Arapović imao velika imanja i kule.

Vjeruje se da temelji Hasan-agine kule postoje i danas, kao i mjesto gdje je Hasanaginica sahranjena. Po narodnoj predaji, njen mezar se nalazi u blizini ruševina kule, na simboličnom mjestu, pored tri bunara, za koje se vjeruje da je iz njih zahvatala vodu.

$\mathrm{Na}$ osnovu historijskih dokumenata, može se zaključiti da je Hasan-aga povrede koje se spominju u baladi zadobio u borbi sa kršćanskim odmetnicima (1645. - 1669.). Kako kazuje balada, dok je ležao ranjen, njegova žena Fatima Arapović (rođ. Pintorović) ga nije nijednom "od stida" posjetila. Međutim ta sintagma "od stida" se mora analizirati u skladu sa tadašnjim strogim patrijarhalnim uređenjem, ali se pri tome ne smije zaboraviti ni stroga "kastinska" podjela koja vlada u bosanskome društvu. Međutim, na koji god način analizirali tu sintagmu, ona je dovela do toga da je Hasan-aga u ponositoj ljutnji poslao ženi poruku da ga ne čeka na dvoru, te da se vrati svojoj majci u Klis. Hasanaginica ga ipak čeka i nada se da će se njen srditi muž predomisliti, no on je po dolasku tjera sa dvora. Hronološki gledajući, to se to se 
najvjerojatnije dešava između 1645. i 1648. godine. Fatimin brat, beg Pintorović, uvrijeđenog begovskog nama, mimo njene želje, ugovara brak sa Imotskim kadijom. Po historijskim dokumentima, to je bio jedan od bogatijih Imoćana, te je beg Pintorović htio izvući ličnu korist iz toga braka, ali ujedno i poniziti Hasana, "običnog agu", te mu pokazati da njegova sestra odlazi na bolje.

Ovakav nesretni splet okolnosti će Hasanaginicu gurnuti u emocionalnu provaliju, ona postaje psihički slomljena žena koja najviše pati za svojom djecom, koja su joj doslovno iz krila istrgnuta. Kraj same balade je nadaleko poznat, Hasanaginica zaustavlja svatove pokraj dvora age Hasan-age, u želji da vidi djecu, da se oprosti od njih, ali i sa nadom da će se njena situacija promijeniti. Hasan-agina surovost upravo u tom momentu dolazi do tačke svoje kulminacije. On doziva djecu, obraća im se riječima: sirotice moje koje majka neće ni da pogleda. Srce nesretne žene i nesretne majke nije moglo više da izdrži, te ona pada na zemlju i umire od bola i nepravde, gledajuću u svoju djecu, ali i u svoga okrutnoga muža (Usput se je s dušom rastavila. Od žalosti gledajuci sirota!).

I ako se saberu historijski dokumenti, narodne legende, i podaci koje nam donosi sama balada, teško je znati šta se od ovoga stvarno dogodilo, a šta je narod pridodao. Možda su se događaji odvijali autentično onima u baladi, a možda se u stvarnosti desi samo poneki fragment od svega onog ispjevanog i ispripovijedanog. Ipak, bez obzira na nejasnu granicu između historije i mita, zna se pouzdano da su slijedeće osobe stvarno postojale: Hasan Arapović - Hasanaga, vjerojatno graničar tadašnje bosanske države, Hasanaginica - Fatima Arapović (rođ. Pintorović), Hasan-agina žena, beg Pintorović, brat Fatime Arapović.

Bosanski književnik Alija Isaković je iznio zanimljivu konstataciju, napola u šali, da je baladu mogla napisati i sama Hasanaginica (Fatima Arapović) nemajući kome drugom da ispriča svoju bol i patnju za djecom. Ni ta se mogućnost ne bi trebala isključiti.

Scena je napravljena tako da paralelno omogućuje odvijanje dvije radnje, lijevo je kula bega Pintorovića na Klisu, a desno je odaja u kuli Hasan-age u Zagvozdu. Da bi se prikazala socijalna razlika, odaja age Hasanage je znatno skromnije namještena. Samom podjelom scene na dva suprotstavljena dijela već scenskom postavkom se začinje dramski sukob koji leži u antagonizmu dvije različite socijalne klase predstavljene u begovima Pintorovićima i agama Arapovićima. Intimna drama ovdje proizlazi iz socijalnih sukoba koji će uroditi tragedijom. Pregradivanjem 
scenskog prostora postiže se neposredna prezentacija simultanih zbivanja na različitim mjestima. Vertikalno pregrađena pozornica na dva dijela, begovske odaje i aginske odaje, sa dijelom simultanim, dijelom sukcesivnim događanjima, na proračunat način postiže se jak kontrast koji ukazuje na nepremostive socijalne razlike, na ustaljenu napetost između bogatijih i siromašnijih, plemenitih i onih manje plemenitih, između gornjeg i donjeg dijela društvenog sloja. Osim ove scenske podijeljenosti, kao dva zasebna segmenta na kojima je poseban akcent vizualnog sloja, javljaju se šator age Hasanage na početku drame i svadbena povorka na samom kraju drame, i oni kao da uokviruju konstantnu podijeljenu scenu.

Sam brak takvog tipa je odmah u startu bio osuđen na propast, jer je to vrijeme postepenog propadanja begovske kaste, što je značilo da se pripadnici te kaste u to vrijeme najviše bore da očuvaju stari nam i obraz. Hasanaginica, kao žena, kao individua je tu potpuno isključena, ona je samo "porodična roba" kojom trguju "stariji". Ni nakon njene udaje taj antagonizam nije prestao, nego je samo postajao još jači $\mathrm{i}$ jači, dok nije došlo do banalnog razloga njegove eskalacije. Dakle, Isaković dramski sukob više gradi na društvenom, nego na intimnom planu i on nastoji da što racionalnije prikaže društveno-historijski kontekst koji je uvjetovao i intimnu tragediju koja je uzrokovala Hasanaginicinu tragičnu smrt. Kako je i sam naglasio u svom predgovoru, najveća želja pri pisanju ovog dramskog teksta mu je prvenstveno da današnjeg čovjeka približi svim onim životnim okolnostima koje su uvjetovale tok događaja koje balada opisuje, pa tako Isaković dosljedno insistira i na narodnom jeziku toga doba. Dosljedno književnoj kritici početkom 70-ih godina prošlog vijeka, Isaković demistificira dotadašnji stav da je osnovni uzrok tragedije "ženski stid", i istražuje dublji uzrok bračnog nesporazuma koji nije samo rezultat njenog stida i njegovog hira, već je, između ostalog, najbolji odraz kastinske nepremostive barijere.

„Ajkuna: "Ne mogu", rě́e nevjesta. Jera, pitam je. "Ne mogu od stida", rè̌e

Majka: Kakav stid, krmaluk begovski! Neće čoeku na noge! Ona je glava, a coek kapa!"

Osnovni antagonizam koji pokreće dramsku radnju su negativne konotacije koje proizlaze iz lika Hasanagina majke i bega Pintorovića, kao personifikacija svojih klasa. Inače je karakterizacija likova u ovoj

${ }^{7}$ Isaković, Alija, Hasanaginica, Drame, "Preporod", Sarajevo, 1995., str. 224. 
drami više u smislu funkcija pripadnosti svojoj klasi, nego u smislu izgrađivanja likova kao individualaca. Hasaniginica svekrva naprosto ne može ,probaviti“ porijeklo svoje snahe i cijelo vrijeme između njih dvije to stoji kao nepremostiva barijera. Ona je tipični primjer "zle svekrve" i ono po čemu Isaković odstupa od balade, jer za razliku od balade, ona u drami podstiče svoga sina da istjera Hasanaginicu.

„Majka: Nevjesta, uұmi se u pamet. Tvoje je da slušaš. Ako si i begovica, nisi se za nebo sverala. Tobe jarabi! Ovo je moj hal i moje ognjišce, dok je mene, beli. I nemoj mi kalem $i$ jariju prid oči. Sina sam izgubila, ha se tvojom jarijom obandijao i sablju odviko! Ne zbori! Ti si sevep! Ja ili ti ovdi! Ne zbori! Sikter!" "

„Hasan-aga: A ti peškes!! Majko, ona je majka djece moje!

Majka: Sikter!

Hasan-aga: Ona je pod našim rzom i obrazom!

Majka: Sikter!

Hasan-aga: (...) Pod našim namom i imenom Arapovića.

Majka: Sikter, rekob" "9

Hasaniginica naprosto ne može funkcionirati normalno. Nju stalno koči splet djevojačkog i muževog prezimena, stalno uslovljavaju njenu nesreću i ona je nužno osuđena na tragediju. U očima svoje okoline ona postaje potpuno dehumanizirana kao obični predmet kastinskog sukobljavanja. Ona nema prava da odlučuje o bilo čemu i njene jedine odluke se svode na one koje su proizašle iz majčinske ljubav, koja je bila jača i od njenog begovskog nama, ali su to odluke koje će je ujedno i odvesti u smrt.

„Beg Pintorović (Prekida) Šta zboriš, pjevaču?

Guslar: (Ne da se zbuniti)

Dočeka ga V ranić Ali-bę̌re,

Isprid njega na noge skočio,

Kod sebe mu misto namistio...

\footnotetext{
8 ibid. str. 232.

${ }^{9}$ Isaković, Alija, Hasanaginica, Drame, "Preporod", Sarajevo, 1995., str. 226.-227.
} 
Beg Pintorovic: (Ljut) Stani,ne valja ti pjesma. Kako može beg skakati na noge prid agom? Gdi to ima? Evo kliškog kadije nek reče. "10

U ovom odlomku jasno je naglašeno da njegova begovska ponositost stoji iznad svega. Isaković je na vrlo uspješan način od baladne građe konstruirao dramski tekst koji u potpunosti dekonstruira socijalne uslove kao nepobitne faktore koji uzrokuju tragični splet okolnosti koja nužno vodi ka tragičnom nesporazumu između supružnika, a sami tim i prema tragičnom kraju glavne junakinje. Zahvaljujući modernoj dramskoj konstrukciji koja, uprkos tome, odražava arhaične baladne elemente, ovaj dramski tekst nosi u sebi nešto od onog lirskog dijela balade i naprosto kipti emocijama.

Isaković pri konstruiranju ove drame nastoji da se što više približi vremenu, jeziku, ali i kulturološkim i socijalno-historijskim aspektima ove balade.

„(...) on pristupa gradi balade bez, pretenzija da je dislocira kao bi je priblị̌io savremenom čovjeku, smatrajući da je poštenije tog covjeka priblị̌iti baladi, njenom vremenu, prostoru $i$ ljudima. Preoblikovanje epskog materijala u dramski Isaković vrši na način stvaralački raspoloženog povjesničara $i$ u osvjetjjavanju osnovnog problema kreće prvenstveno od socijalno-historijskih okolnosti, pa tragicni nesporazum dvaju bića prebacuje sa intimnog na drustveni plan. Stradanje Hasanaginice nije uslovljeno samo njenim stidom i Hasanaginim hirom, nego prije svega, njihovim kastinskim raqlikama, pa tako Hasanaginica nije toliko žrtva moralnih običaja koliko jaza izmedu aga i begova. "11

\section{5) Zaključak}

Kao dramski pisac (To, Generalijum, Kraljevski sudbeni sto, Hasanaginica...) Isaković će se realizirati krajem sedamdesetih i početkom osamdesetih godina prošlog vijeka. Njegovo eksperimentiranje sa dramskim stvaralaštvom bilo je isprovocirano tečnošću i sočnošću njegovog pripovjednog dijaloga, pa se njegova književna realizacija u dramskim formama javlja kao neminovnost. On spada u grupu dramskih pisaca koji su formalno i poetički neopterećeni, pa u tom periodu svestrasno istražuje moderni teatar i preispituje utjecaje modernog teatra od kojeg preuzima svojevrsnu egzistencijalističku poetiku. Isaković je, kao dramski pisac, uvijek zagledan u prošlost, korespondirajući sa

10 ibid. str. 226.-227.

${ }^{11}$ Isaković, Alija, To, Drame, "Preporod", Sarajevo, 1995., str. 249. 
suvremenošću, on se vezuje za našu domaću bošnjačku književnu, narodnu i kulturnu tradiciju, koju, dakle, oblikuje na nov i originalan način, izvlačeći univerzalne poruke i smisao.

\section{Literatura:}

1. Isaković, Alija: Drame, "Preporod", Sarajevo, 1995.

2. Katnić-Bakaršić, Marina: Stilistika dramskog diskursa, Vrijeme, Zenica, 2003.

3. Kraj utopije i pozorišta. Kritike i eseji (1985. - 2000.), Otkrovenje, Beograd Sterijino pozorje, Novi Sad, 2000.

4. Lešić, Josip: Dramska književnost II, Institut za književnost/Svjetlost, Sarajevo, 1991.

5. Lešić, Josip: Savremena drama i pozorište u Bosni i Hercegovini, Sterijino pozorje, Novi Sad, 1984.

6. Lešić, Josip: Savremena dramska književnost u Bosni i Hercegovini (tema i struktura), U: Drame, Savremena književnost naroda $i$ narodnosti BiH u 50 knjiga, Svjetlost, Sarajevo, 1985.

7. Lešić, Josip: V rijeme prošlo - vrïjeme sadašnje, Scena, 1970, br. 1-2.

8. Lešić, Zdenko: Nova čitanja. Poststrukturalistička čitanka, Buybook, Sarajevo, 2003.

9. Lešić, Zdenko: Teorija drame kroz stoljeća, Svjetlost, Sarajevo, 1977.

10. Lešić, Zdenko: Kapidžić-Osmanagić, Hanifa, Katnić-Bakaršić, Marina i Kulenović, Tvrtko: Zbornike radova grupe autora/ autorica, Suvremena tumačenja književnosti, Sarajevo Publishing, Sarajevo, 2007.

11. Lukić, Sveta: Savremena jugoslovenska drama, Prosveta, Beograd, 1968.

12. Melchinger, Siegfried: Povijest političkog kazališta, Grafički zavod Hrvatske, Zagreb, 1989.

13. Miočinović, Mirjana: Moderna teorija drame, Nolit, Beograd, 1981.

14. Muzaferija, Gordana, Rizvanbegović, Fahrudin, Vujanović, Vojislav: Antologija bošnjačke drame XX vijeka, Alef, Sarajevo, 2000.

15. Muzaferija, Gordana: Bosanskohercegovačka drama ili Dijalog s vremenom. U: Ciniti za teatar, Centar za kulturu i obrazovanje, Tešanj, 2004.

16. Muzaferija, Gordana: Bošnjačka književnost u književnoj kritici, Novija književnost Drama, Alef, Sarajevo, 1998.

17. Muzaferija, Gordana: Između historije $i$ savremenosti (bosanskohercegovačka drama 1967. - 1977.), U: Čniti za teatar, Centar za kulturu i obrazovanje, Tešanj, 2004.

18. Pavis, Patrice: Pojmovnik teatra, Izdanja antibarbarus, Zagreb, 2004.

19. Pfister, Manfred: Drama. Teorija i analiza, Hrvatski centar ITI, Zagreb, 1998. 
20. Selenić, Slobodan: Dramski pravi XX veka, Umetnička akademija u Beogradu, Beograd, 1971.

21. Kraj utopije i pozorista. Kritike i eseji (1985. - 2000.), Otkrovenje, Beograd Sterijino pozorje, Novi Sad 2000. 
Amra Memic, MA

\section{THE DICHOTOMY OF THE WORLD IN THE DRAMA WORKS OF ALIJA ISAKOVIC}

\section{ABSTRACT}

Reader can perceive in all the dramas of Alija Isakovic images of the past and the modern, historical and contemporary world. However, in either case, Isakovic seeks the unchanging image of human duplicity. He makes an effort in marking the extremes of buman existence, a ceaseless clash of creational and destructive principles, which we can equally recognize in the cosmic and anthropological, in the past and in the present. He gives an analytical outline of reflection in the buman actions and objects and the phenomena around them. These contours harmonicaly blend into a more or less complete and coherent motive, creating a bundle of analytical data without finished synthesis, with impersonal open pictures for the reader's commitment and conclusion. As a playwrighter (To, Generalijum, Hasanaginica...), Isakovic blossoms during the late seventies and early eighties of the last century. He belongs to the group of playwrighters who at that time investigated and examined the modern theater and its influences. Peering into the past while corresponding with modernity, Isakovic is linked to our local Bosniak literary, folk and cultural traditions, which he, therefore, formes in a new and original way, drawing out a universal message and meaning.

Keywords: Alija Isakovic, the dichotomy of the world, the two present tenses, drama, poetry, To, Generalijum, Bosniak folk ballad Hasanaginica, dialogues, monologues, stage directions, existentialism, absurdity, myth, history, antagonism ... 
م. عَمرة مَميتش

\section{ثنائية صورة العالم في أعمال علي إيساكوفيتش الدرامية}

\section{الخلاصة}

في كل أعمال علي إيساكوفيتش يمكن أن نلحظ صور العالم القديم والمعاصر،

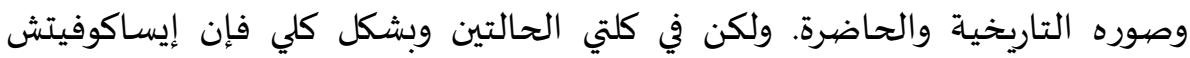
يبحث عن صورة الإنسان الازدواجية، وجهوده منصبة على تحديد أقصى الوجود الإنساني، اللامنقطع من المبادئ البناءة والهدامة والتي سوف نتعرف عليها في كل ما هو كوني وأنثروبولوجي، وفي كل ما هو ماضي وحاضر. هو يعطي صوراً تحليلية لانعكاسات

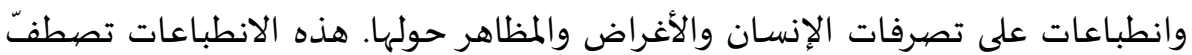
بشكل فسيفسائي إلى باعث قصصي كلي متناسق يتكون من معلومات تحليلية بدون

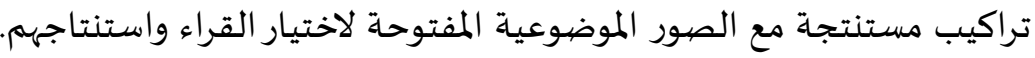

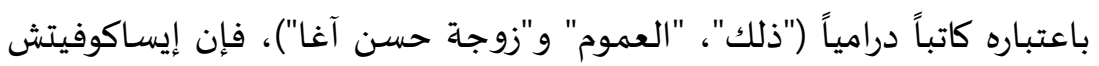
سيبلغ الذروة نهاية السبعينات ومطلع الثمانينات من القرن الماضي وهو من كتّاب

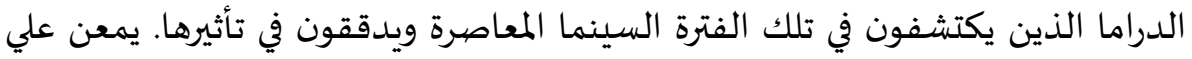
إيساكوفيتش النظر في الماضي ويتواصل مع الحاضر ويرتبط بالتراث الأدبي الشعبي

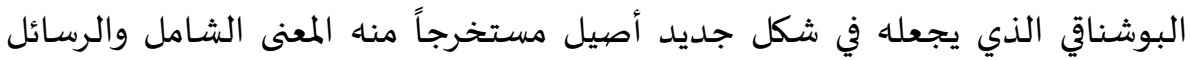
العامة.

الكلمات الرئيسة: علي إيساكوفيتش، ثنائية العالم، حاضران، أعمال درامياة،

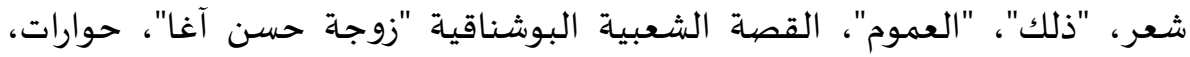
حديث فردي، وجودية، سخافة، أسطورة، تاريخ، تضاد ... 